\title{
Genetic Diversity of Indigenous Chicken (Gallus Gallus domesticus) from Ecozones of Egypt and Kingdom of Saudi Arabia
}

\author{
Ayman Sabry ${ }^{1,2 *}$, Alaa Ahmed Mohamed ${ }^{1,3}$, Mohamed Hassen ${ }^{1,4}$ \\ ${ }^{1}$ Biology Department, Faculty of Science, Taif University, Taif, KSA \\ ${ }^{2}$ Cell Biology Department, National Research Center, Dokki, Giza, Egypt \\ ${ }^{3}$ Department of Animal Reproduction and AI, National Research Center, Dokki, Giza, Egypt \\ ${ }^{4}$ Department of Genetics, Faculty of Agriculture, Minufiya University, Al Minufya, Egypt \\ Email: *amsabry@gmail.com
}

How to cite this paper: Sabry, A., Mohamed, A.A. and Hassen, M. (2021) Genetic Diversity of Indigenous Chicken (Gallus Gallus domesticus) from Ecozones of Egypt and Kingdom of Saudi Arabia. Open Journal of Applied Sciences, 11, 775-787. https://doi.org/10.4236/ojapps.2021.116057

Received: May 20, 2021

Accepted: June 27, 2021

Published: June 30, 2021

Copyright $\odot 2021$ by author(s) and Scientific Research Publishing Inc. This work is licensed under the Creative Commons Attribution International License (CC BY 4.0).

http://creativecommons.org/licenses/by/4.0/

\begin{abstract}
Genetic diversity of two chicken ecotypes from Ismailia-Egypt (ISM) and TaifSaudi Arabia (TA) was evaluated using 39 microsatellites. DNA was extracted from blood of 25 chickens/ecotype. The number of alleles was 157 and 138, the number of alleles/locus averaged $4.2 \pm 2.2$ and $3.6 \pm 1.6$, and the highest number of private alleles was 9 and 5 for ISM and TA, respectively. Percentage of shared alleles between the two ecotypes was $45 \%$. This panel of markers is reasonably informative as the mean polymorphic information content for ISM and TA was $0.47 \pm 0.21$, and $0.41 \pm 0.2$. Similar average of observed heterozygosity was attained for both ecotypes. Conversely, averages of expected heterozygosity differed between two ecotypes, $0.52 \pm 0.23$ vs. $0.45 \pm$ 0.21 for ISM and TA. 8 and 12 loci have significantly deviated from HWE of ISM and TA. Estimate of genetic distance was 0.2 and $\mathrm{F}_{\mathrm{ST}}$ index was 0.29 . Results showed only $6 \%$ of genetic diversity is shared between these two ecotypes.
\end{abstract}

\section{Keywords}

Ecotypes, Genetic Diversity, Microsatellite, Polymorphic Information Content, Hardy Weinberg Expectation

\section{Introduction}

Chickens' ecotypes are being utilized in rural and backyard farming of developing countries all over the world. The significance of these ecotypes in the rustic economy is tremendous in various counties [1]-[7]. This significance is due to 
affordable low production cost, scavenging competency as well as adaptability to harsh and stressful environmental conditions [8] [9]. Moreover, chicken ecotypes supply work security to the family as well as getting the accessibility of food. Jobless youth and ladies can likewise acquire pay through poultry cultivating [10]. Still, local ecotypes have low egg productivity and light mature body size [11] [12].

The poultry industry is globally dominated by commercial chicken breeds, where breeding strategy is based on few chicken genotypes. Such a strategy has the shortcoming of erosion of valuable genetic resources (ecotypes) [13]. Their low productivity does not meet the global demands of intensive production systems, as such ecotypes could barely compete with commercial breeds. Therefore, ecotypes are negatively selected regardless of their good quality of egg and meat, disease resistance as well as adaptation to the local environment [13]. The establishment of a framework for preserving these genetic resources is of need [8]. Investigating the genetic makeup of indigenous chicken breeds was carried out in several studies [11] [14] [15] [16] and has been used as a sampling guide in genetic diversity research [17].

At Taif governorate ( $1.7 \mathrm{~km}$ above sea) local chickens are acclimated to the rough environment of high altitudes, such as low oxygen tension, as well as daily temperature fluctuations [18] [19] [20] [21].

Microsatellites (MS) markers are normally used because they are plentiful, codominant, randomly spread throughout the genome, and very polymorphic, also because of their reproducibility [22] [23]. This coherence has made MS markers a dependable tool for genetic diversity evaluation and assessment in many commercial chicken breeds and ecotypes [13] [18] [19] [20]. Quite a few MS markers are available in chickens and have been utilized to develop linkage maps in numerous chicken breeds [22] [24]. These markers introduced efficient machinery to QTL research and have additionally been effectively utilized to consider the hereditary associations among and within chicken populations [23].

Osaman et al., [25] utilized the complete sequence of mitochondrial DNA D-loop to explain the genetic descent of Egyptian indigenous chicken and Asian chicken. Results of this study revealed that both Egyptian native chicken and West and Central Asian chicken are sharing the same common ancestor as they branched together in the same clade. However, this work did not include native chicken strains from Saudi Arabia. Therefore, the current study was carried out as an attempt to introduce a better understanding of the genetic characterization of 2 ecotypes sampled from two different ecozones at Taif (Saudi Arabia) and Ismailia (Egypt). A dense microsatellites panel of 39 markers was genotyped for two ecotypes.

\section{Materials and Methods}

\subsection{Sample Collection}

Chicken samples were collected from individual framers in local village either in 
Ismailia (ISM) or Taif (TA) with same age as possible. From each location 25 chicken were collected and blood sample collected from chicken using EDTA contain collected tube.

\subsection{DNA Extraction}

Collected blood samples were used for DNA isolation using DNA extraction kit (QIAGEN) according to manufacture manual. Extracted DNA quality checked by electrophoresis in a minigel while the quantity checked spectrophotometrically using NanoDrop 2000C (Spectronic Genesys, Thermo Electron Corporation). DNA samples were stored at $-20^{\circ} \mathrm{C}$ until microsatellites analysis.

\subsection{Microsatellite Genotyping}

Thirty nine MS markers were utilized to assess DNA polymorphism of these 2 ecotypes. These MS markers were chosen based on reports by the International Society of Animal Genetics (ISAG)-FAO to think about the hereditary assorted variety of chickens [26] and additionally 150 microsatellites were investigated for the segregation of five thoroughbred KNC lines [20]. Names of each of the $39 \mathrm{MS}$ markers, chromosome number and respective allelic size are appeared in Table 1.

Table 1. Marker's name, Chromosomal number (Chr) and allele size (bp) of 39 genotyped Microsatellites markers.

\begin{tabular}{|c|c|c|c|c|c|}
\hline Marker & Chr & Allele size(bp) & Marker & $\mathrm{Chr}$ & Allele size(bp) \\
\hline MCW248 & 1 & $205-225$ & MCW029 & 5 & $139-189$ \\
\hline LEI141 & 2 & $220-242$ & MCW014 & 6 & $164-182$ \\
\hline MCW087 & 2 & $267-283$ & MCW183 & 7 & $296-326$ \\
\hline MCW063 & 2 & $132-150$ & ROS019 & 7 & $119-143$ \\
\hline LEI234 & 2 & $217-315$ & ADL278 & 8 & $114-126$ \\
\hline MCW206 & 2 & $226-240$ & GCT016 & 9 & $108-154$ \\
\hline MCW288 & 2 & $108-122$ & ADL259 & 9 & $106-146$ \\
\hline MCW264 & 2 & $224-240$ & MCW067 & 10 & $175-184$ \\
\hline MCW127 & 3 & $227-241$ & MCW228 & 10 & $221-239$ \\
\hline MCW016 & 3 & $134-146$ & MCW216 & 13 & $139-149$ \\
\hline MCW037 & 3 & $152-156$ & MCW104 & 13 & $189-225$ \\
\hline MCW222 & 3 & $221-225$ & MCW213 & 13 & $288-316$ \\
\hline LEI166 & 3 & $354-370$ & MCW123 & 14 & $79-89$ \\
\hline MCW098 & 4 & $261-265$ & ADL293 & 17 & $105-119$ \\
\hline LEI094 & 4 & $254-280$ & ADL304 & 18 & $137-159$ \\
\hline ADL317 & 4 & $178-204$ & MCW165 & 23 & $114-118$ \\
\hline MCW295 & 4 & $88-106$ & LEI074 & 26 & $224-240$ \\
\hline ROS013 & 5 & $220-242$ & MCW069 & 26 & $158-176$ \\
\hline MCW078 & 5 & $135-147$ & LEI135 & 28 & $131-142$ \\
\hline ADL292 & 5 & $110-138$ & & & \\
\hline
\end{tabular}


Polymerase Chain Reaction (PCR) amplifications were in absolute volume of $20 \mu \mathrm{L}, 50 \mathrm{ng}$ of genomic DNA, $10 \mathrm{pmol}$ of fluorescent dye (FAM, VIC, NED, PET) labeled modified forward primer and normal reverse primer (Applied Biosystems, USA), $2.5 \mathrm{mM}$ of each dNTPs (GeNet Bio, Korea), $10 \mathrm{X}$ reaction buff (GeNet Bio, Korea), 2.5 unit of prime Taq DNA polymerase (GeNet Bio, Korea). The PCR was performed in an initial denaturation at $95 \mathrm{C}$ for $10 \mathrm{~min}$ followed by 35 cycles of $30 \mathrm{sec}$ of denaturation at $95 \mathrm{C}, 30 \mathrm{sec}$ of annealing at $60 \mathrm{C}, 30 \mathrm{sec}$ of extension at $72 \mathrm{C}$ and final extension at $72 \mathrm{C}$ for $10 \mathrm{~min}$ using My-Genie 96 Thermal Cycler (Bioneer, Korea). The PCR products were initially electrophoresis on $3 \%$ agarose gel with ethidium bromide $(\mathrm{EtBr})$ and confirmed whether they gave single PCR DNA band under the UV light. When the bands were clearly appeared, further genotyping will be performed. For the microsatellite genotyping, more than 20 times diluted PCR products will be used. The genotyping reaction contained $1 \mu \mathrm{L}$ of diluted PCR products, $10 \mu \mathrm{l}$ of Hi-Di Formamide (Applied Biosystems, USA) and $0.1 \mu \mathrm{L}$ of GeneScan-500 LIZ size standard marker (Applied Biosystems, USA). After dilution, genotyping reaction mixture was denatured for $2 \mathrm{~min}$ at $95 \mathrm{C}$ and fragment analysis was performed using capillary array in Genetic analyzer 3130xl (Applied Biosystems, USA). The MS genotypes will be identified using GeneMapper ver.3.7 (Applied Biosystems, USA).

\section{Data Analyses}

Exploratory data analysis and graphical representations of the results were carried out under R statistical environment R Core Team [27]. Fundamental measures of genetic diversity, such as total number of alleles, allele frequencies, mean number of alleles, observed, and expected heterozygosity (Nei, 1987) were computed using adegenet R statistical package [28]. Deviation from Hardy-Weinberg equilibrium (HWE) using chi square test, and phylogenic analysis using Nei's distance [29] as well as population subdivision was examined using Weir and Cockerham [30] unbiased estimator of Wrights fixation indices $\left(\mathrm{F}_{\mathrm{IT}}, \mathrm{F}_{\mathrm{ST}}\right.$ and $\left.\mathrm{F}_{\mathrm{IS}}\right)$ [31] was carried out using "pegas" package R Population and Evolutionary Genetics Analysis System [32]. The null hypothesis was that the estimates were not significantly different from zero, and the level of significance $(P<0.01)$ was adjusted using Bonferroni correction. Allelic richness number was estimated using hierfstat package [33]. Phylogenetic analysis was carried out using APE package [34].

\section{Results and Discussion}

Figure $1 \&$ Figure 2 show a descriptive overview of number of alleles per locus, Polymorphic Information Content (PIC) observed and expected Heterozygosity $\left(\mathrm{H}_{\text {obs }}\right.$ and $\left.\mathrm{H}_{\text {exp }}\right)$ for both ISM and TA ecotypes.

For the number of alleles per locus a considerable difference was observed in both ecotypes. The ISM ecotype has a sum of 157 alleles, number of alleles per 


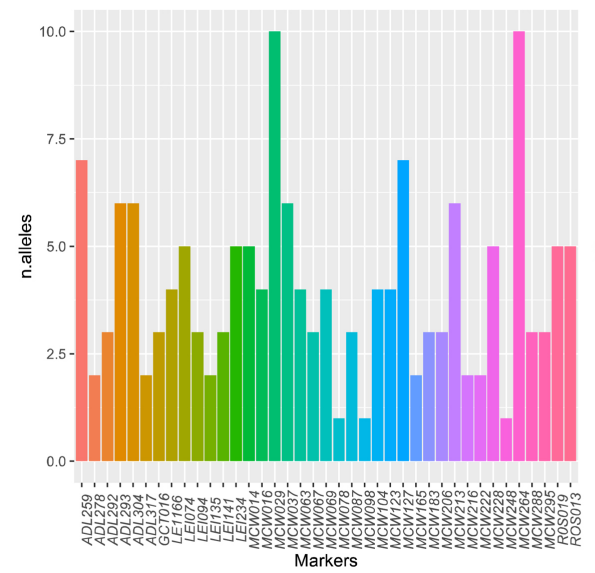

(a) no. alleles

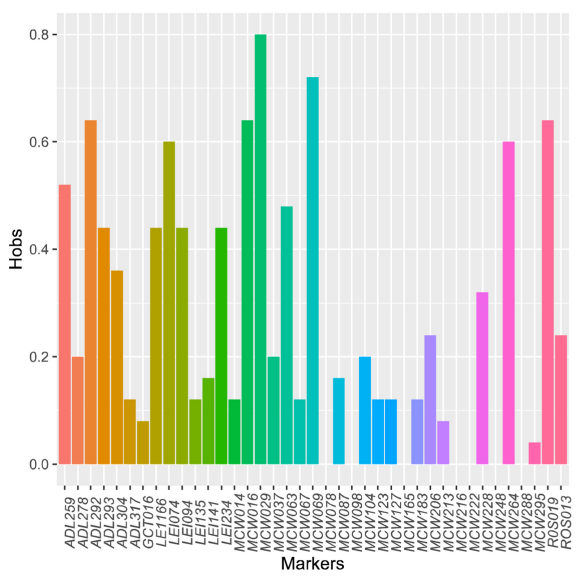

(c) $H_{o b s}$

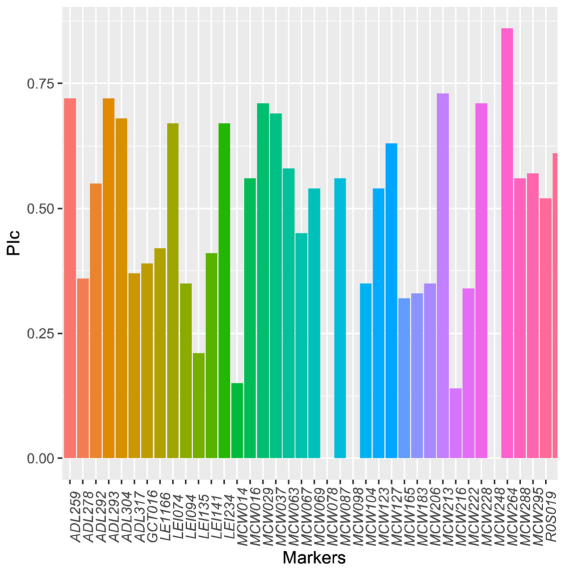

(b) PIC

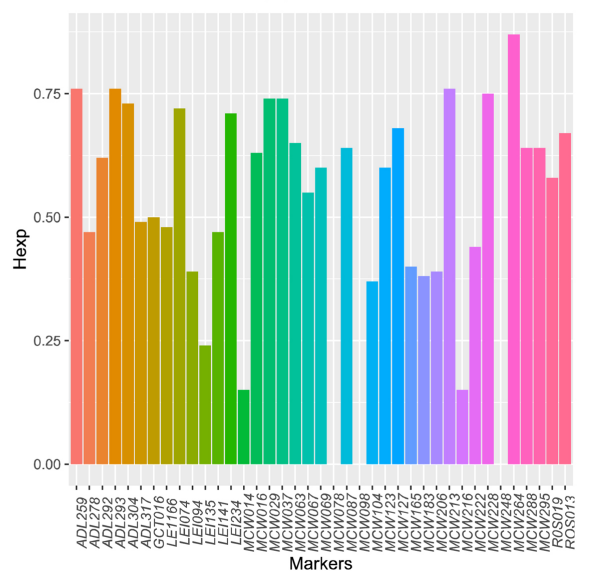

(d) $H_{\text {exp }}$

Figure 1. (a) Number of Alleles, (b) Polymorphic Information Content "PIC", (c) Observed heterozygosity " $\mathrm{H}_{\mathrm{obs}}$ " and (d) Expected heterozygosity " $\mathrm{H}_{\exp }$ " of ISM ecotype.

locus ranged from 1 to 10 alleles, averaged $4.2 \pm 2.2$. The TA ecotype exhibited a lower number of alleles sum 138, the number of alleles per locus ranged from 1 to 7 averaged $3.6 \pm 1.6$. These estimates are lower than the reported on other studies, e.g. Abebe et al., [13] on Swedish native chicken (4.7), Muchadeyi et al., [16] on Zimbabwe ecotypes (9.7), Van-Marle-Koster et al., [35] on South Africa native chicken (6.1), and Ramadan et al., [36] on native Egyptian and commercial chicken breeds (7.7). These lower estimates of the present study could be attributed to utilizing a larger number of loci. The number of alleles per locus could also be represented as "allelic richness". The number of observed alleles is basically a function of sample size. Allelic richness $\left(R_{t}\right)$ was estimated across all loci (Table 2). One definition of $R_{t}$ is the mean number of alleles per locus [37]. The significance of $R_{t}$ is that decrease in $R_{t}$ might result in reducing ability of the population to acclimate to future environmental changes, as such an assorted variety is the rough material for evolutionary forces, for example, common determination [38].

The mean of polymorphic information content (PIC) for ISM and TA ecotype were $0.47 \pm 0.21$, and $0.41 \pm 0.2$. This means that this penal of markers are 


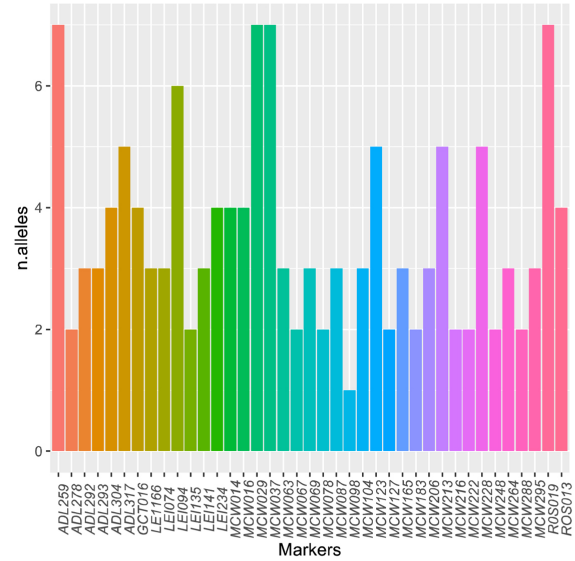

(a) n. alleles

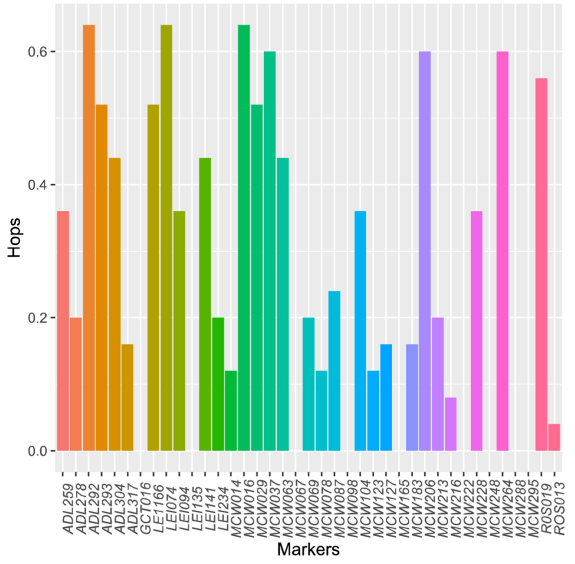

(c) $H_{o b s}$

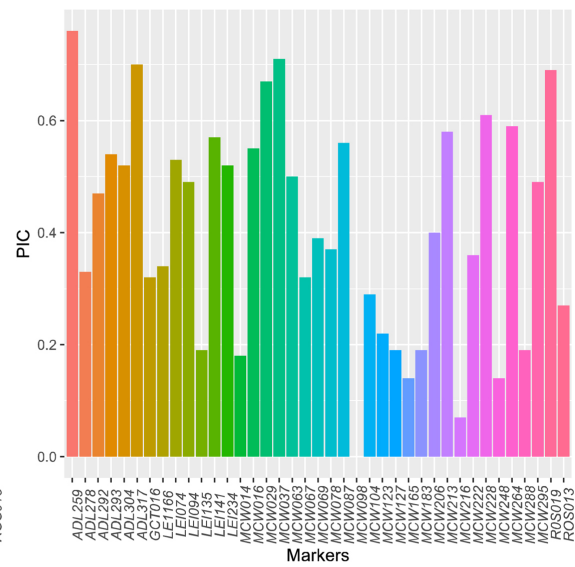

(b) PIC

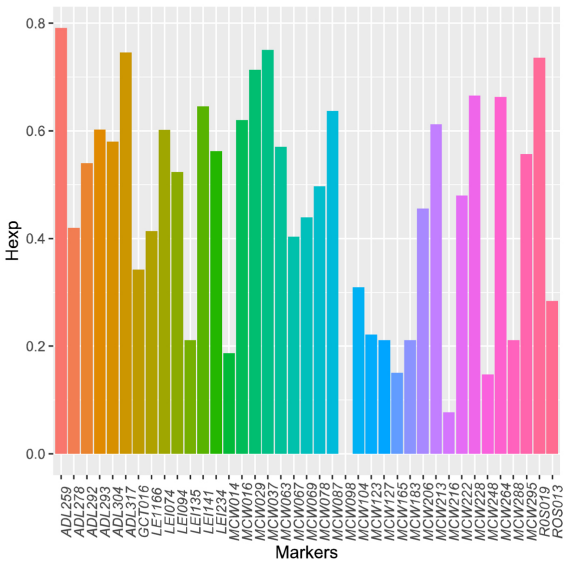

(d) $H_{e x p}$

Figure 2. (a) Number of Alleles, (b) Polymorphic Information Content "PIC", (c) observed heterozygosity " $\mathrm{H}_{\mathrm{obs}}$ " and (d) Expected heterozygosity " $\mathrm{H}_{\exp }$ " of TA ecotype.

reasonably informative as PIC exceeds 0.25 Botstein et al., (1980). For ISM ecotype $54 \%$ of markers are highly informative as PIC was higher than $50 \%$, where only $38 \%$ of TA's markers were highly informative. The mean value of PIC in this study was smaller than the estimates of other studies on different native breeds e.g., Seo et al., [20] estimate of PIC was 0.77 on five native Korean lines, Ramadan et al., [36] reported 0.65 on six Egyptian native breeds, and Choi et al., [39] on commercial Korean native breed reported mean PIC value of 0.68 , and Soltan et al., [40] estimation of PIC was 0.84 on Sinai and Norfa Egyptian native chicken. However, lower estimate of 0.55 was reported by Abebe et al., [13] on five local Swedish breeds. Again, these differences in mean value of PIC could be ascribed to the dense panel of markers were used in the present study.

The presence of private alleles was also investigated (Table 3). Only 4 markers did show private alleles between the two ecotypes, namely ADL278, MCW087, MCW222 and MCW295. For ISM ecotype the highest number of private alleles was 9, where the highest number of private alleles for TA ecotype was only 5 . Existence of private alleles might be indicating of diversifying selection of these specific alleles. In general, the percentage of shared alleles between the two 
Table 2. Allelic Richness $\left(\mathrm{R}_{\mathrm{t}}\right)$ of genotyped Microsatellites markers across ISM and TA ecotypes.

\begin{tabular}{cccccc}
\hline Marker & ISM & TA & Marker & ISM & TA \\
\hline MCW222 & 2 & 2 & MCW295 & 6 & 5 \\
MCW165 & 2 & 3 & ADL293 & 6 & 3 \\
ADL304 & 6 & 4 & MCW123 & 8 & 5 \\
ROS013 & 5 & 4 & MCW014 & 5 & 4 \\
MCW127 & 7 & 2 & GCT016 & 3 & 4 \\
LEI141 & 3 & 3 & MCW104 & 4 & 3 \\
MCW078 & 1 & 2 & ADL259 & 7 & 7 \\
LEI234 & 5 & 4 & MCW098 & 1 & 1 \\
MCW216 & 2 & 2 & ADL292 & 3 & 3 \\
MCW016 & 4 & 4 & MCW288 & 3 & 2 \\
MCW069 & 4 & 3 & MCW037 & 6 & 7 \\
MCW087 & 3 & 3 & MCW228 & 5 & 5 \\
MCW063 & 4 & 3 & R0S019 & 5 & 7 \\
MCW248 & 1 & 2 & LEI074 & 5 & 3 \\
MCW067 & 3 & 2 & LEI135 & 2 & 2 \\
ADL278 & 2 & 2 & LEI094 & 3 & 6 \\
MCW183 & 3 & 2 & ADL317 & 2 & 5 \\
LE1166 & 4 & 3 & MCW213 & 6 & 5 \\
MCW206 & 3 & 3 & MCW264 & 10 & 3 \\
MCW029 & 10 & 7 & & & \\
\hline
\end{tabular}

Table 3. Number of private alleles of genotyped Microsatellites markers across ISM and TA ecotypes.

\begin{tabular}{cccccc}
\hline Markers & ISM & TA & Markers & ISM & TA \\
\hline MCW165 & 0 & 1 & MCW123 & 1 & 2 \\
ADL304 & 4 & 2 & MCW014 & 3 & 2 \\
ROS013 & 3 & 2 & GCT016 & 3 & 4 \\
MCW127 & 5 & 0 & MCW104 & 3 & 2 \\
LEI141 & 2 & 2 & ADL259 & 3 & 3 \\
MCW078 & 1 & 2 & MCW098 & 1 & 1 \\
LEI234 & 2 & 1 & ADL292 & 1 & 1 \\
MCW216 & 1 & 1 & MCW288 & 2 & 1 \\
MCW016 & 4 & 4 & MCW037 & 2 & 3 \\
MCW069 & 2 & 1 & MCW228 & 3 & 3 \\
MCW063 & 2 & 1 & R0S019 & 3 & 5 \\
MCW248 & 0 & 1 & LEI074 & 2 & 0 \\
MCW067 & 1 & 0 & LEI135 & 1 & 1 \\
MCW183 & 2 & 1 & LEI094 & 1 & 4 \\
LE1166 & 3 & 2 & ADL317 & 0 & 3 \\
MCW206 & 1 & 1 & MCW213 & 5 & 4 \\
MCW029 & 5 & 2 & MCW264 & 9 & 2 \\
ADL293 & 4 & 1 & & & \\
\hline
\end{tabular}


ecotypes was $45 \%$. The incidence of heterozygous individuals in population is measured by the observed proportion of heterozygosity $\left(\mathrm{H}_{\mathrm{obs}}\right)$. A similar average values of $\left(\mathrm{H}_{\mathrm{obs}}\right)$ for both ecotypes were attained although narrower range of values were found for TA ecotype. For the ISM ecotype the $\mathrm{H}_{\mathrm{obs}}$ ranged from 0.0 to 0.8 with average of $0.27 \pm 0.24$. For the TA ecotype the $\mathrm{H}_{\mathrm{obs}}$ ranged from 0.0 to 0.64 with average of $0.27 \pm 0.23$. The expected heterozygosity $\left(\mathrm{H}_{\exp }\right)$ is an estimate of the likelihood that a pair of gametes arbitrary picked from genetic stock are of various alleles. In the contrary to $\mathrm{H}_{\mathrm{obs}}$ the averages of $\mathrm{H}_{\text {exp }}$ differed between the two ecotypes, $0.52 \pm 0.23$ vs. $0.45 \pm 0.21$ for ISM and TA. This variability of the two parameters might be result of variation in evolutionary process on each of the two ecotypes.

Test for deviation from Hardy Weinberg Equilibrium was also carried out. For the ISM ecotypes only 8 loci were significantly deviated from Hardy Weinberg expectation, where 12 loci of TA ecotype.

Breaking up the genetic diversity within and among populations is best described through Wright's F-statistics (Wright, 1951). Table 4 shows Wright's fixation indices $\left(\mathrm{F}_{\mathrm{ST}}, \mathrm{F}_{\mathrm{it}}\right.$, and $\left.\mathrm{F}_{\mathrm{IS}}\right)$ across ISM and TA ecotypes for the genotyped microsatellites markers. Figure 3 shows a boxplot for the estimates of Wright's

Table 4. Wright's fixation indices $\left(\mathrm{F}_{\mathrm{ST}}, \mathrm{F}_{\mathrm{it}}\right.$, and $\left.\mathrm{F}_{\mathrm{IS}}\right)$ across ISM and TA ecotypes for the genotyped Microsatellites markers.

\begin{tabular}{|c|c|c|c|c|c|c|c|}
\hline Marker & $\mathrm{F}_{\mathrm{ST}}$ & $\mathrm{F}_{\mathrm{it}}$ & $\mathrm{F}_{\text {is }}$ & Marker & $\mathrm{F}_{\mathrm{ST}}$ & $\mathrm{F}_{\mathrm{it}}$ & $\mathrm{F}_{\text {is }}$ \\
\hline MCW222 & 0.01 & 0.01 & 1 & MCW295 & -0.01 & -0.03 & 0.98 \\
\hline MCW165 & 0 & 0 & 1 & ADL293 & 0.05 & 0.1 & 0.42 \\
\hline ADL304 & 0.07 & 0.12 & 0.53 & MCW123 & 0.02 & 0.03 & 0.84 \\
\hline ROS013 & 0.12 & 0.22 & 0.82 & MCW014 & -0.02 & -0.03 & 0.8 \\
\hline MCW127 & 0.03 & 0.06 & 0.81 & GCT016 & 0.15 & 0.26 & 0.95 \\
\hline LEI141 & 0.04 & 0.07 & 0.62 & MCW104 & 0.01 & 0.01 & 0.59 \\
\hline MCW078 & 0.21 & 0.35 & 0.91 & ADL259 & 0.01 & 0.03 & 0.51 \\
\hline LEI234 & 0.06 & 0.11 & 0.62 & MCW098 & 0.32 & 0.48 & 1 \\
\hline MCW216 & -0.02 & -0.03 & 0.93 & ADL292 & 0.09 & 0.17 & 0.14 \\
\hline MCW016 & 0.13 & 0.23 & 0.17 & MCW288 & 0.05 & 0.1 & 1 \\
\hline MCW069 & 0.15 & 0.26 & 0.37 & MCW037 & 0.04 & 0.07 & 0.55 \\
\hline MCW087 & 0 & -0.01 & 0.76 & MCW228 & 0.05 & 0.1 & 0.61 \\
\hline MCW063 & 0.08 & 0.15 & 0.41 & R0S019 & 0.08 & 0.15 & 0.25 \\
\hline MCW248 & -0.02 & -0.04 & 1 & LEI074 & 0.02 & 0.03 & 0.22 \\
\hline MCW067 & -0.01 & -0.01 & 0.92 & LEI135 & 0.19 & 0.32 & 0.91 \\
\hline ADL278 & -0.02 & -0.03 & 0.73 & LEI094 & 0.11 & 0.19 & 0.45 \\
\hline MCW183 & 0 & -0.01 & 0.79 & ADL317 & 0.02 & 0.04 & 0.83 \\
\hline LE1166 & 0.15 & 0.27 & 0.3 & MCW213 & 0.06 & 0.12 & 0.84 \\
\hline MCW206 & 0 & 0 & 0.39 & MCW264 & 0.05 & 0.1 & 0.32 \\
\hline MCW029 & 0.01 & 0.01 & 0.23 & & & & \\
\hline
\end{tabular}




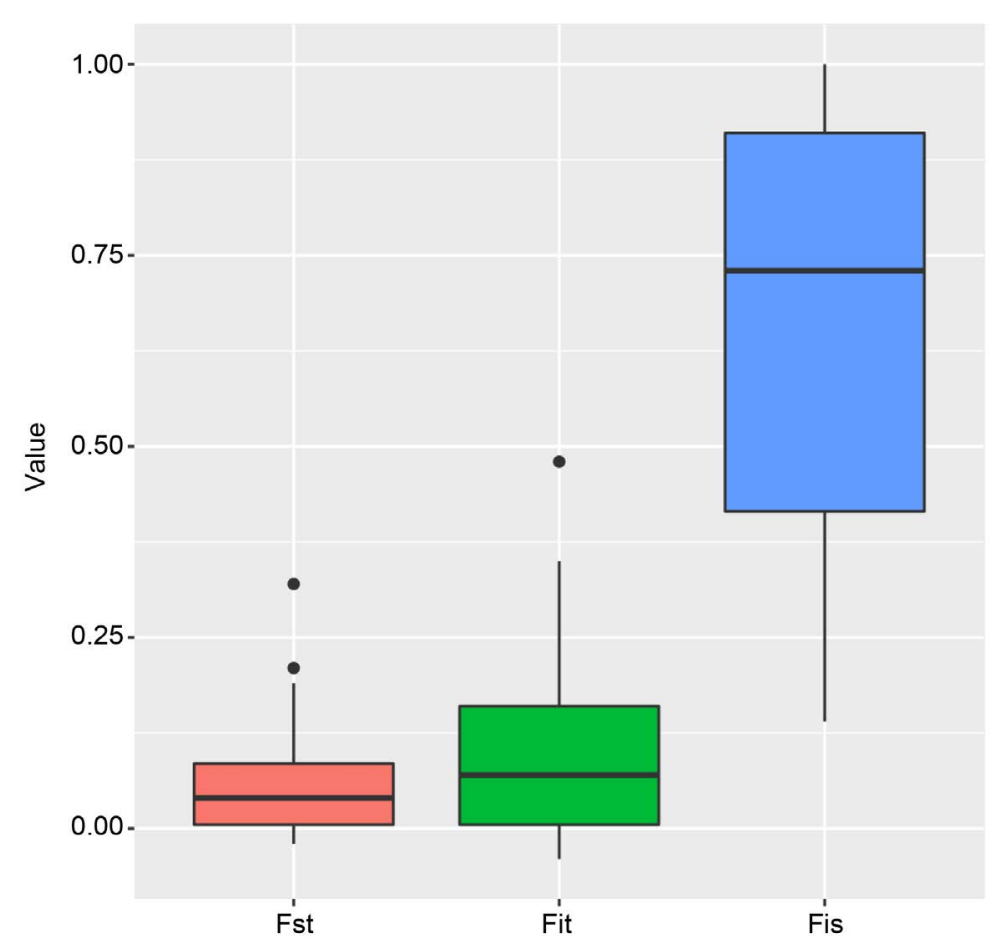

Figure 3. Wright's fixation indices $\left(\mathrm{F}_{\mathrm{ST}}, \mathrm{F}_{\mathrm{IT}}\right.$, and $\left.\mathrm{F}_{\mathrm{IS}}\right)$ across ISM and TA ecotypes across 39 microsatellites loci.

$\mathrm{F}_{\mathrm{ST}}, \mathrm{F}_{1 \mathrm{~T}}$ and $\mathrm{F}_{1 \mathrm{~s}}$. The average values of the three indices were all positive. The average of $\mathrm{F}_{\mathrm{ST}}$ was small (0.06) which indicates similarity of allele frequencies within each breed, which in turn indicate that genetic variation among ecotypes accounted for only $6 \%$, which shows homology of allele frequencies of both ecotypes [41], thus indicate that genetic variation between ecotypes represents $6 \%$ of entire genetic variation. This small estimate of $\mathrm{F}_{\mathrm{ST}}$ could be considered as indicative that none of the $39 \mathrm{MS}$ loci were under selection [42] [43]. The estimate of $\mathrm{F}_{\mathrm{ST}}$ ranged from -0.02 to 0.32 . This estimate was lower than the estimates of Abebe et al. [13] on Swedish local breed, Seo et al. [20] on Korean chicken as well as Ramadan et al., [36], Soltan et al., [40] on Egyptian native breeds.

Average value of global heterozygosity index $\left(\mathrm{F}_{\mathrm{IT}}\right)$ was 0.102 , ranged from -0.04 to 0.48 . This index could be considered as correlation between alleles within individuals with respect to combined sample [41]. The inbreeding coefficient $\left(\mathrm{F}_{\mathrm{IS}}\right)$ across the $39 \mathrm{MS}$ loci averaged 0.65 ranged from 0.14 to 1.00 . This estimate is higher than the other studies on indigenous chicken breeds e.g. 0.187 on Swedish breeds [13], 0.0093 on Korean indigenous breeds [20] and 0.018 on Egyptian indigenous breeds [36], but Soltan et al., [40] reported somewhat closer estimate on Sinai and Norfa indigenous Egyptian chicken breeds. $\mathrm{F}_{\mathrm{IS}}$ is also taken as an indicative of endangerment potentiality and devised to assess the conservation priorities [44]. Thus, when $\mathrm{F}_{\mathrm{IS}}$ is lower than 0.05 , breed is not in danger; the range from 0.05 to 0.15 , breed is potentially endangered; between 0.15 0.25 , they are slightly endangered; between $0.25-0.40$, they are endangered; and more than 0.40 , breed is seriously endangered [36] [40]. 
Diversity assessment between population is normally quantified by estimation of genetic distance. Both Nei's genetic distance [29] as well as Nei's pairwise $\mathrm{F}_{\mathrm{ST}}$ index between all pairs of populations [45] was estimated for the two ecotypes over the 39 MS loci. The estimate of Nei's genetic distance was 0.2 where Nei's pairwise $\mathrm{F}_{\mathrm{ST}}$ was 0.29 . This small value is comfortable with the percentage of shared alleles of the two ecotypes $45 \%$.

\section{Conclusion}

The results of the present study are, presumably, the first to recount the genetic diversity between two ecozones Egyptian and Saudi Arabia ecotypes. To be concluded, a small proportion of genetic diversity due to allele frequency differences was between these two ecotypes was only $6 \%$. This result is also supported by small estimate of Nei's genetic distance $(0.2)$ as well as small Nei's pairwise $\mathrm{F}_{\mathrm{ST}}$ (0.29). The percentage of shared alleles of the two ecotypes was $45 \%$.

\section{Conflicts of Interest}

The authors declare no conflicts of interest regarding the publication of this paper.

\section{References}

[1] Barua, A. and Yoshimura, Y. (1997) Rural Poultry Keeping in Bangladesh. Worlds Poultry Science Journal, 53, 392-394. https://doi.org/10.1079/WPS19970031

[2] Gueye, E.H.F. (1998) Village Egg and Fowl Meat Production in Africa. Worlds Poultry Science Journal, 54, 82-86. https://doi.org/10.1079/WPS19980007

[3] Khan, A.G. (2008) Indigenous Breeds, Crossbreds and Synthetic Hybrids with Modified Genetic and Economic Profiles for Rural Family and Small-Scale Poultry Farming in India. World's Poultry Science Journal, 64, 405-415. https://doi.org/10.1017/S0043933908000135

[4] Vali, N. (2008) Indigenous Chicken Production in Iran: A Review. Pakistan Journal of Biological Sciences, 11, 2525-2531. https://doi.org/10.3923/pjbs.2008.2525.2531

[5] Bett, H.K., Peters, K.J. and Bokelman, W. (2011) Hedonic Price Analysis to Guide in Breeding and Production of Indigenous Chicken in Kenya. Livestock Research for Rural Development, 23. http://www.lrrd.org/lrrd23/6/bett23142.htm

[6] Magothe, T., Mokeno, T.O., Muhuyi, W.B. and Kahi, A.K. (2012) Indigenous chicken Production in Kenya: I. Current Status. World s Poultry Science Journal, 68, 119-132. https://doi.org/10.1017/S0043933912000128

[7] Magothe, T., Mokeno, T.O., Muhuyi, W.B. and Kahi, A.K. (2012) Indigenous Chicken Production in Kenya: II. Prospects for Research and Development. World s Poultry Science Journal, 68, 133-144. https://doi.org/10.1017/S004393391200013X

[8] Mpenda, F.N., Schilling, M.A., Campbell, Z., Mngumi, E.B. and Buza, J. (2019) The Genetic Diversity of Local African Chickens: A Potential for Selection of Chickens Resistant to Viral Infections. Journal of Applied Poultry Research, 28, 1-12. https://doi.org/10.3382/japr/pfy063

[9] Habimana, R., Okeno, T.O., Ngeno, K., Mboumba, S., Assam, P., Gbotto, A.A. and et al. (2020) Genetic Diversity and Population Structure of Indigenous Chicken in Rwanda Using Microsatellite Markers. PLoS ONE, 15, e0238966. 
https://doi.org/10.1371/journal.pone.0225084

[10] Hanssen, S.A. and Kumar, P.M. (2016) Importance of Indigenous Breeds of Chicken for Rural Economy and Their Improvements for Higher Production Performance. Scientifica, 2016, Article ID: 2604685. https://doi.org/10.1155/2016/2604685

[11] Rudresh, B.H., Murthy, H.N.N., Jayashankar, M.R., Nagaraj, C.S., Kotresh, A.M. and Byregowda, S.M. (2015) Microsatellite Based Genetic Diversity Study in Indigenous Chicken Ecotypes of Karnataka. Veterinary World, 8, 970-976. https://doi.org/10.14202/vetworld.2015.970-976

[12] Mahoro, J., Muasya, T.K., Mbuza, F., Habimana, R. and Kahi, A.K. (2017) Characterization of Indigenous Chicken Production Systems in Rwanda. Poultry Science, 96, 4245-4252. https://doi.org/10.3382/ps/pex240

[13] Abebe, A.S., Mikko, S. and Johansson, A.M. (2015) Genetic Diversity of Five Local Swedish Chicken Breeds Detected by Microsatellite Markers. PLOS ONE, 10, e0120580. https://doi.org/10.1371/journal.pone.0120580

[14] Msoffe, P.L.M., Mtambo, M.M.A., Minga, U.M., Yongolo, M.G.S., Gwakisa, P.S. and Olsen, J.E. (2001) Identification and Characterization of the Free Ranging Local Chicken Ecotypes in Tanzania. Paper Presented at Proceedings of SUS-MU ENRECA Workshop on Farm Animal Genetic Resources in Tanzania, Morogoro, November 2001.

[15] Tadelle, D., Kijora, C. and Peters, K.J. (2003) Indigenous Chicken Ecotypes in Ethiopia: Growth and Feed Utilization Potentials. International Journal of Poultry Science, 2, 144-152. https://doi.org/10.3923/ijps.2003.144.152

[16] Muchadeyi, F.C., Eding, H., Wollny, C.B., Groeneveld, E., Makuza, S.M., Shamseldin, R., Simianer, H. and Weigend, S. (2007) Absence of Population Substructuring in Zimbabwe Chicken Ecotypes Inferred Using Microsatellite Analysis. Animal Genetics, 38, 332-339. https://doi.org/10.1111/j.1365-2052.2007.01606.x

[17] Wimmers, K., Ponsuksili, S., Hardge, T., Valle-Zarate, A., Mathur, P.K. and Horst, P. (2000) Genetic Distinctness of African, Asian, and South American Chickens. Animal Genetics, 31, 159-165. https://doi.org/10.1046/j.1365-2052.2000.00605.x

[18] Groen, A.F., Crooijmans, R.P.M.A., VanKampen, A.J.A., Van-derbeek, S., Vander Poel, J.J. and Groenenm, M.A.M. (1996) Microsatellite Polymorphism in Commercial Broiler and Layer Lines. Poultry Science, 75, 904-909.

[19] Shahbazi, S., Mirhosseini, S. and Romanov, M. (2007) Genetic Diversity in Five Iranian Native Chicken Populations Estimated by Microsatellite Markers. Biochemical Genetics, 45, 63-75. https://doi.org/10.1007/s10528-006-9058-6

[20] Seo, D.W., Hoque, M.R., Choi, N.R., Sultana, H., Park, H.B., Heo, K.N., Kang, B.S., Lim, H.T., Lee, S.H., Jo, C. and Lee, J.H. (2013) Discrimination of Korean Native Chicken Lines Using Fifteen Selected Microsatellite Markers. Asian-Australas Journal of Animal Sciences, 26, 316-322. https://doi.org/10.5713/ajas.2012.12469

[21] Sabry, A., Ramadan, S., Hassan, M.M., Mohamed, A.A., Mohammedein, A. and Inoue-Murayama, A. (2021) Assessment of Genetic Diversity among Egyptian and Saudi Chicken Ecotypes and Local Egyptian Chicken Breeds Using Microsatellite markers. Journal of Environmental Biology, 42, 33-39. https://doi.org/10.22438/jeb/42/1/MRN-1572

[22] Groenen, M., Cheng, H.H., Bumstead, N., Benkel, B.F., Briles, B.F., Burke, T., Burt, D.W., Crittenden, L.B., Dodgson, J., Hillel, J., Lamont, S., de Leon, A.P, Soller, M., Takahash, H. and Vigna, A. (2000) A Consensus Linkage Map of the Chicken Genome. Genome Research, 10, 173-174.

[23] Hillel, J., Groenen, M.A., Tixier-Boichard, M., Korol, A.B., David, L., Kirzhner, 
V.M., Burke, T., Barre-Dirie, A., Crooijmans, R.P., Elo, K., Feldman, M.W., Freidlin, P.J., Mäki-Tanila, A., Oortwijn, M., Thomson, P., Vignal, A., Wimmers, K. and Weigend, S. (2003) Biodiversity of 52 Chicken Populations Assessed by Microsatellite Typing of DNA Pools. Genetics Selection and Evolution, 35, Article No. 533. https://doi.org/10.1186/1297-9686-35-6-533

[24] Nones, K., Ledur, M.C., Ruy, D.C., Baron, E.E., Moura, A.S.A.M.T. and Coutinho, L.L. (2005) Genetic Linkage Map of Chicken Chromosome 1 From A Brazilian Resource Population. Scientia Agriccola, 62, 12-17. https://doi.org/10.1590/S0103-90162005000100003

[25] Osaman, S.A.M., Yonezawa, T. and Nishibori, M. (2016) Origin and Genetic Diversity of Egyptian Native Chicken Based on Complete Sequence of Mitochondrial DNA D-Loop Region. Poultry Science, 95, 1248-1256.

https://doi.org/10.3382/ps/pew029

[26] FAO (Food and Agriculture Organization of the United Nations) (2011) Molecular Genetic Characterization of Animal Genetic Resources. Animal Production and Health Guidelines, No. 9, Food and Agriculture Organization of the United Nations, Rome.

[27] R Core Team (2021) R: A Language and Environment for Statistical Computing. R Foundation for Statistical Computing, Vienna. https://www.R-project.org/.

[28] Jombart, T. (2008) Adegenet A R Package for the Multivariate Analysis of Genetic Markers. Bioinformatics, 24, 1403-1405.

https://doi.org/10.1093/bioinformatics/btn129

[29] Nei, M. (1987) Molecular Evolutionary Genetics. Columbia University Press, New York. https://doi.org/10.7312/nei-92038

[30] Weir, B.S. and Cockerham, C.C. (1984) Estimating F-Statistics for the Analysis of Population Structure. Evolution, 38, 1358-1370.

https://doi.org/10.1111/j.1558-5646.1984.tb05657.x

[31] Wright, S. (1949) The Genetical Structure of Populations. Annals of Eugenics, 15, 323-354. https://doi.org/10.1111/j.1469-1809.1949.tb02451.x

[32] Paradis, E. (2010) Pegas: An R Package for Population Genetics with an IntegratedModular Approach. Bioinformatics, 26, 419-420.

https://doi.org/10.1093/bioinformatics/btp696

[33] Goudet, J. and Jombart, T. (2020) Hierfstat: Estimation and Tests of Hierarchical F-Statistics. R Package Version 0.5-7. https://CRAN.R-project.org/package=hierfstat

[34] Paradis, E. and Schliep, K. (2019) Ape 5.0: An Environment for Modern Phylogenetics and Evolutionary Analyses in R. Bioinformatics, 35, 526-528.

https://doi.org/10.1093/bioinformatics/bty633

[35] Van-Marle-Koster, E. and Nel, L.H. (2000) Genetic Characterization of Native Southern African Chicken Populations: Evaluation and Selection of Polymorphic Microsatellite Markers. South African Journal of Animal Science, 30, 1-6. https://doi.org/10.4314/sajas.v30i1.3866

[36] Ramadan, S., Kayang, B.B., Inoue, E., Nirasawa, K., Hayakawa, H., Ito, S. and Inoue-Murayama, M. (2012) Evaluation of Genetic Diversity and Conservation Priorities for Egyptian Chickens. Open Journal of Animal Sciences, 2, 183-190. https://doi.org/10.4236/ojas.2012.23025

[37] Hughes, R.A., Inouye, B.D., Johnson, M.T.J., Underwood, N. and Vellend, M. (2008) Ecological Consequences of Genetic Diversity. Ecology Letters, 11, 609-623. https://doi.org/10.1111/j.1461-0248.2008.01179.x

[38] Fisher, R. (1930) The Genetical Theory of Natural Selection. Oxford University Press, Oxford. https://doi.org/10.5962/bhl.title.27468 
[39] Choi, N.R., Seo, D.W., Jemaa, S.B., Sultana, H., Heo, K.N., Jo, C. and Lee, J.H. (2015) Discrimination of the Commercial Korean Native Chicken Population Using Microsatellite Markers. Journal of Animal Science and Technology, 57, Article No. 5. https://doi.org/10.1186/s40781-015-0044-6

[40] Soltan, M., Farrag, S., Enab, A., Abou-Elewa, E., El-Safty, S. and Abushady, A. (2018) Sinai and Norfa Chicken Diversity Revealed by Microsatellite Markers. South African Journal of Animal Science, 48, 307-315. https://doi.org/10.4314/sajas.v48i2.11

[41] Holsinger, K.E. and Weir, B. (2009) Genetics in Geographically Structured Populations: Defining, Estimating, and Interpreting $\mathrm{F}_{\mathrm{ST}}$. Nature Reviews Genetics, 10, 639-650. https://doi.org/10.1038/nrg2611

[42] Beaumont, M.A. and Balding, D. (2004) Identifying Adaptive Genetic Divergence among Populations from Genome Scans. Molecular Ecology, 13, 969-980.

https://doi.org/10.1111/j.1365-294X.2004.02125.x

[43] Excoffier, L., Hofer, T. and Foll, M. (2009) Detecting Loci under Selection in a Hierarchically Structured Population. Heredity, 103, 285-298.

https://doi.org/10.1038/hdy.2009.74

[44] Simon, D.L. and Buchenauer, D. (Eds.) (1993) Genetic Diversity of European Livestock Breeds. Results of Monitoring by the EAAP Working Group on Animal Genetic Resources; EAAP Animal Genetic Data Bank, Institute of Animal Breeding and Genetics, School of Veterinary Medicine, Hannover. EAAP Publication, Hannover.

[45] Nei, M. (1973) Analysis of Gene Diversity in Subdivided Populations. Proceedings of the National Academy of Sciences of the United States of America, 70, 3321-3323. https://doi.org/10.1073/pnas.70.12.3321 